\title{
LIFE CYCLE OF THE SPIDER, UROCTEA LIMBATA (C.L. KOCH) (ARANEAE: OECOBIIDAE) IN EGYPT
}

\author{
SALLAM, GIHAN M.E. ${ }^{1}$, NAHLA A.I. ABD EL-AZIM ${ }^{1}$ \& M. A. MOHAFEZ ${ }^{2}$ \\ 1- Plant Protection Research Institute, ARC, Dokki, Giza, Egypt \\ 2- Faculty of Agriculture, Al-Azhar University, Cairo, Egypt
}

(Manuscript received 18 March 2015)

\begin{abstract}
$\mathrm{T}$ he spiders, Uroctea limbata (C.L. Koch,1843), of family Oecobiidae, were collected from greenhouses in Giza Governorate, Egypt. Their life cycle was studied in laboratories at $26-28^{\circ} \mathrm{C}$ and $60-70 \%$ R.H. The male ones reached their maturity after 6-7 spiderling instars, with an average of $230.7 \pm 3.4$ days, while the females after 7-8 spiderling instars with an average of (273.1 \pm 3.1 days). Spiders were fed on different instars of the cotton leaf worm. Food consumption and mating behaviour were observed. This study is a necessary step to know the role of the spider, U. limbata in the biological control, especially in greenhouses.

Keywords: Spiders, Araneae, Oecobiidae, Uroctea limbata, life cycle, food consumption, Egypt.
\end{abstract}

\section{INTRODUCTION}

Family Oecobiidae Blackwall, 1862 has a worldwide distribution and is represented in several countries both by native and some cosmopolitan and synanthropic species (Santos \& Gonzaga, 2003). It includes six genera and 110 species; one of them is genus Uroctea Dufour, 1820 that includes18 species distributed all over the world (Platnick, 2014). In Egypt, there are two genera and seven species of Oecobiidae; two species of them belong to genus Uroctea, i.e. U. durandi (Latreille, 1809) and U. limbata (C.L. Koch, 1843) (El-Hennawy, 2006). U. limbata is recorded from Alexandria, Abu Galoum, Nabq and Ras Mohammed in Egypt (El-Hennawy, 2006). Now, it is recorded from Giza too.

Uroctea limbata is the first dominant ground species inside greenhouses followed by Nurscia albomaculta (Lucas, 1846) while it is the second dominant species after $N$. albomaculta in the open fields of cucumber and pepper plants (Sallam et al., 2009).

There is not any published biological study on $U$. limbata in or outside Egypt till now. Therefore, it is necessary to study its life cycle and to try to know its role in the agroecosystem especially inside greenhouses. 


\section{MATERIALS AND METHODS}

The spiders of Uroctea limbata (Fig.1) were found under stones, under plants and in the greenhouses corners. Two egg sacs of $U$. limbata were collected from cucumber and pepper greenhouses in Dokki region, Giza governorate and kept in plastic vials ( $3 \mathrm{~cm}$ diameter $\times 5 \mathrm{~cm}$ length). The newly hatched spiderlings were transferred and individually reared in translucent plastic container cells. They were fed once every two days on different stages of $1^{\text {st }} 4^{\text {th }}$ instars of larvae cotton leaf worm, Spodoptera littoralis (Boisduval, 1833). Each spider was supplied with known number of the larvae of $S$. littoralis as a prey for the first spiderlings till the adulthood. The rearing vials were kept in an incubator at $26-28 \pm 1^{\circ} \mathrm{C}$ and $60-70 \%$ R.H. Spider individuals were examined every two days and the numbers of consumed prey individuals were recorded and replaced by other live ones. After reaching male adulthood, young female were reared together to observe mating behaviour (Fig. 2) and oviposition. Obtained data recorded for 20 adult males and females.

\section{RESULTS AND DISCUSSION}

\section{Egg sac, eggs and incubation period}

The egg sac is spherical in shape, white in colour at first, covered with a lot of silk web and it becomes dark before hatching. The eggs inside the egg sac are spherical and white at the beginning and then become dark before hatching. Thirty six individuals hatched and emerged from the two egg sacs through a round pore at the tip of the egg sac. They were kept under laboratory conditions. The incubation period of $U$. limbata eggs lasted for $27.5 \pm 2.1$ days inside the two egg sacs.

\section{Spiderlings}

The spiderlings passed through 6-7 instars for males and 7-8 instars for females during their development (Table 1). These results agree with El-Hennawy \& Mohafez (2003) for males of Stegodyphus dufouri (Audouin, 1825) (Family: Eresidae) but it differs for females (7 instars). Also, these results agree with Sallam (2004) for Steatoda paykulliana (Walckenaer, 1805) (Family: Theridiidae) for males but it differs for females (6-8 insatrs).

Spiderling duration averages were $12.2 \pm 2.0 \& 19.6 \pm 3.1 ; 20.5 \pm 2.8 \& 19.8 \pm 2.2 ;$ $21.8 \pm 3.0 \& 33.3 \pm 3.3 ; 33.5 \pm 3.8 \& 44.2 \pm 2.7 ; 43.3 \pm 3.7 \& 46.6 \pm 2.0 ; 45.9 \pm 1.4 \&$ $49.7 \pm 1.8 ; 37.0 \pm 2.5 \& 35.5 \pm 1.6$ and $20.8 \pm 2.0$ days, for male and female, respectively. Total periods of spiderlings development differed according to sexes which were shorter for males than females. 
The shortest instars were the 1st and the 2 nd ones for both male and female; this data agree with that obtained by Sallam (2004) for males and females respectively, but not agree with that obtained by Sallam \& El-Hennawy (2003) when the duration was longer during the first instar and then decreased during the $2^{\text {nd }}$ and $3^{\text {rd }}$ instars for the spider N. albomaculata.

Forty percent of males became adult after six moults, while sixty percent moulted seven times. Most females (80\%) reached maturity after eight moults, while only $20 \%$ moulted seven times. The longest duration was the 6 th instar for both females and males, respectively. The shortest instars were the 1st through the 3rd ones for both males and females.

\section{Sex ratio}

The sex ratio of the spider, $U$. limbata adults was $1: 1$ (male: female) which coincided with the spiders N. albomaculata (Sallam \& El-Hennawy, 2003).

Table 1. Duration of the different developmental stages of the oecobiid Spider

\begin{tabular}{|c|c|c|c|c|c|c|}
\hline \multirow{3}{*}{$\begin{array}{c}\text { Developmental } \\
\text { Stages }\end{array}$} & \multicolumn{6}{|c|}{ Duration (Days) } \\
\hline & \multicolumn{3}{|c|}{ Male } & \multicolumn{3}{|c|}{ Female } \\
\hline & Range & Mean & S.D & Range & Mean & S.L \\
\hline $1^{\text {st }}$ Instar & $11-16$ & 12.2 & 2.0 & $16-22$ & 19.6 & 3.1 \\
\hline $2^{\text {nd }}$ Instar & $18-26$ & 20.5 & 2.8 & $19-26$ & 19.8 & 2.2 \\
\hline $3^{\text {rd }}$ Instar & $20-30$ & 21.8 & 3.0 & $25-35$ & 33.3 & 3.3 \\
\hline $4^{\text {th }}$ Instar & $30-38$ & 33.5 & 3.8 & $38-49$ & 44.2 & 2.7 \\
\hline $5^{\text {th }}$ Instar & $35-47$ & 43.3 & 3.7 & $44-50$ & 46.6 & 2.0 \\
\hline $6^{\text {th }}$ Instar & $44-48$ & 45.9 & 1.4 & $45-52$ & 49.7 & 1.8 \\
\hline $7^{\text {th }}$ Instar & $35-40$ & 37.0 & 2.5 & $35-40$ & 35.5 & 1.6 \\
\hline $8^{\text {th }}$ Instar & -- & -- & -- & $20-25$ & 20.8 & 2.0 \\
\hline Life cycle & $225-235$ & 230.7 & 3.4 & $267-277$ & 273.1 & 3.1 \\
\hline
\end{tabular}

1 2
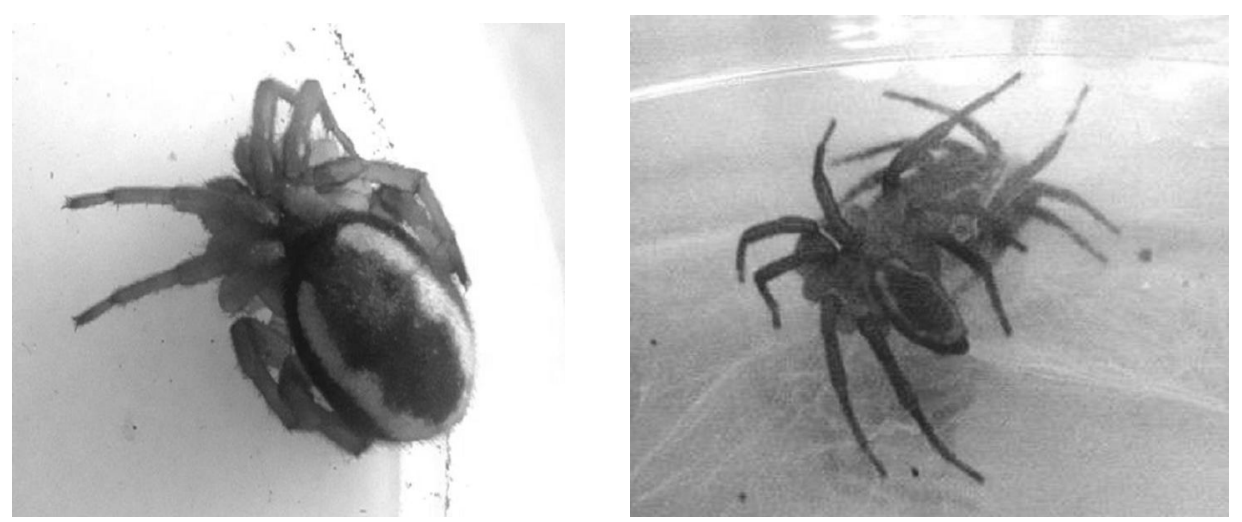

Figs. 1-2. Uroctea limbata (C.L. Koch, 1843). 1. Subadult Female. 2.

Mall and Female at pre-copulation position. 


\section{Food Consumption}

During the study the food consumption of spider, U. limbata, different spiderling instars and adults when fed on various spiders instars of $S$. littoralis larvae. Both first and second instars of spiderlings were fed on the first instar of $S$. littoralis. Third and fourth instars of spiderlings were fed on the second instar of prey. Fifth and sixth instars of spiderlings were fed on the third instar of the prey, while the seventh and eighth instars of spiderlings were fed on the fourth instar of the prey. Number of consumed prey by different spiderling instars is represented in Table (2).

The spider attacked the $S$. littoralis larvae seizing the membrane between head and thorax to feed and suck its contents. The spiderling instars could consume $343 \pm 4.4 \&$ $408 \pm 4.4$ larvae of $S$. littoralis for male and female respectively (Table 2). Females consumed more larvae of $S$. littoralis than males; this results agree with Sallam \& ElHennawy (2003), El-Hennawy \& Mohafez (2003) and Sallam (2004).

Table 2. Food consumption of the oecobiid spider Uroctea limbata.

\begin{tabular}{|c|c|c|c|c|c|c|}
\hline \multirow{2}{*}{$\begin{array}{c}\text { Developmental } \\
\text { Stages }\end{array}$} & \multicolumn{5}{|c|}{ Number of consumed prey individuals } \\
\cline { 2 - 7 } & Range & Mean & S.D. & Range & Mean & S.D. \\
\cline { 2 - 7 } & $15-30$ & 20.8 & 3.0 & $18-30$ & 22 & 2.2 \\
\hline $1^{\text {st }}$ Instar & $18-30$ & 23.1 & 2.1 & $22-33$ & 24.1 & 1.9 \\
\hline $2^{\text {nd }}$ Instar & $20-35$ & 23.8 & 3.3 & $28-43$ & 28 & 3.9 \\
\hline $3^{\text {rd }}$ Instar & $31-45$ & 39.6 & 4.0 & $33-62$ & 44 & 3.2 \\
\hline $4^{\text {th }}$ Instar & $50-90$ & 72.2 & 1.4 & $59-100$ & 94 & 3.7 \\
\hline $5^{\text {th }}$ Instar & $60-102$ & 92.3 & 2.9 & $60-118$ & 97.0 & 3.1 \\
\hline $6^{\text {th }}$ Instar & $72-111$ & 90 & 2.8 & $75-120$ & 92 & 3.9 \\
\hline $7^{\text {th }}$ Instar & -- & -- & -- & $35-93$ & 53 & 2.5 \\
\hline $8^{\text {th }}$ Instar & $246-398$ & 343 & 4.4 & $322-523$ & 408 & 4.4 \\
\hline Life $^{*}$ cycle & & & &
\end{tabular}

\section{ACKNOWLEDGMENT}

The authors are indebted to Col. Hisham K. El-Hennawy (Cairo) who identified the spider species and kindly revised a draft of the manuscript. 


\section{REFERENCES}

1. El-Hennawy, H.K. 2006. A list of Egyptian spiders (revised in 2006). Serket, 10(2): 65-76.

2. El-Hennawy, H.K. \& Mohafez, M.A. 2003. Life history of Stegodyphus dufouri (Audouin, 1825) (Arachnida: Araneida: Eresidae) in Egypt, A step on the way from asocial to social. Serket, 8(3): 113-124.

3. Platnick, N. I. 2014. The world spiders catalog, version 14.5. American Museum of Natural History, online at http://research.amnh.org/ entomology/spiders/catalog/index.html

4. Sallam, G.M.E. 2004. Life Cycle of Steatoda paykulliana (Walckenaer, 1805) in Egypt (Araneida: Theridiidae). Serket, 9(2): 37-40.

5. Sallam, G.M. \& El-Hennawy, H.K. 2003. Biological aspects of Nurscia albomaculata (Lucas,1846) (Arachnida: Araneida: Titanoecidae) in Egypt. Serket, 8(4): 147-150.

6. Sallam, G.M.E., Abd El-Azim, N.A.I. \& Mohafez, M.A. 2009. Seasonal occurrence of spider (Araneida) in open and green house fields of cucumber and pepper in Egypt. Egyptian Academic J. Bio. Sci. (Zoology), 1(1): 29-36.

7. Santos, A.J. \& Gonzaga, M.O. 2003. On the spider genus Oecobius Lucas, 1846 in South America (Araneae, Oecobiidae). J. Natural History, 37: 239-252. 


\title{
Uroctea limbata (C. L. Koch), دورة حياة العنكبوت في مصر (Araneae: Oecobiidae)
}

\author{
جيهان محمد السيد سلام ، نهلة علي ابراهيم عبد العظيم 1، محمد عبد العال محافظ2 \\ 1- معهز بحوث وقاية النباتات - مركز البحوث الزراعية - الدقي - الجبزة - مصر \\ 2- كلبة الزراعة - جامعة الازهر - القاهرة - مصرابهر
}

تم جمع العنكبوت Uroctea limbata من الصوب الز اعيه للخيار و الفلفل من محافظة الجيزة

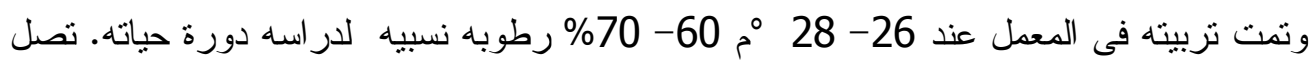

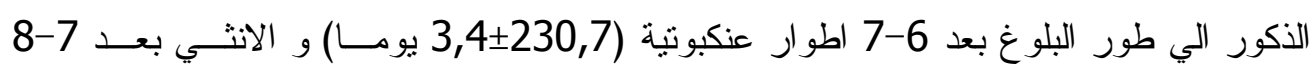

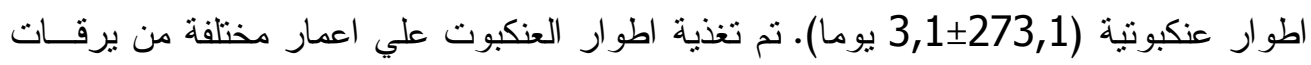

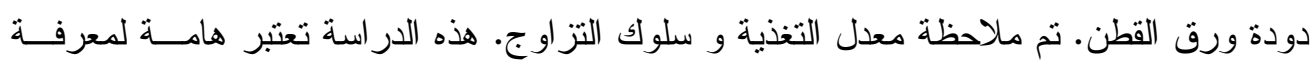
دور العنكبوت محل الدر اسه في مجال المكافحة البيولوجية خاصة داخل نظام الصوب الزر اعية. 